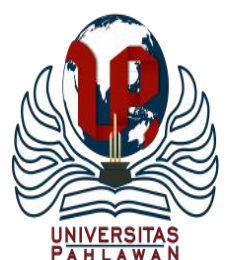

Edukatif : Jurnal Ilmu Pendidikan Volume 3 Nomor 5 Tahun 2021 Halm 2827 - 2833

EDUKATIF: JURNAL ILMU PENDIDIKAN

Research \& Learning in Education

https://edukatif.org/index.php/edukatif/index

\title{
Pengaruh Metode Demonstrasi melalui Google Meet terhadap Hasil Belajar IPA Peserta Didik di Sekolah Dasar
}

\author{
Ibnu Fathoni ${ }^{1 凶}$, Safrul Kodri ${ }^{2}$ \\ Universitas Muhammadiyah Prof. Dr. Hamka, Indonesia ${ }^{1,2}$ \\ E-mail : ibnufathoni99@gmail.com ${ }^{1}, \underline{\text { safrul_kodri@ uhamka.ac.id }}^{2}$
}

\begin{abstract}
Abstrak
Kegiatan pendidikan yang dilakukan secara online saat ini akibat wabah covid-19 memerlukan perhatian yang lebih. Dari observasi peneliti, ditemukan suatu masalah terkait proses pembelajaran online yaitu tentang metode pembelajaran dan akses pembelajaran yang baru berbasis aplikasi, sehingga berpengaruh pada hasil belajar peserta didik akibat minat dan fokus yang kurang pada pembelajaran online. Penelitian ini bertujuan untuk mengetahui dampak metode demonstrasi melalui Google Meet terhadap hasil belajar IPA peserta didik kelas IV. Jenis penelitian yaitu Kuantitatif Eksperimen dengan metode True Eksperiment Design dan desain penelitian Posttest-Only Control Design dengan sampel berjumlah 52 peserta didik. Tes pilihan ganda digunakan sebagai instrumen yang sebelumnya diuji valid dengan rumus Korelasi Point Biserial dan diuji reliabilitas dengan rumus KR-20. Pengolahan data melalui uji normalitas Liliefors dan uji homogenitas Fisher. Uji-t digunakan untuk pengujian hipotesis dan hasil thitung $=3,026$ pada ttabel $=2,0105$, maka disimpulkan bahwa thitung >ttabel $(3,026>2,0105)$. Maka terdapat pengaruh metode demonstrasi melalui Google Meet terhadap hasil belajar IPA peserta didik kelas IV di SD Islam Nurul Hidayah Depok.
\end{abstract}

Kata Kunci: Metode Demonstrasi, Google Meet, Hasil Belajar IPA.

\begin{abstract}
Educational activities carried out online at this time due to the COVID-19 outbreak require more attention. From the researchers' observations, it was found a problem related to the online learning process, namely about learning methods and access to new learning based on applications, so that it affects student learning outcomes due to lack of interest and focus on online learning. This study aims to determine the impact of the demonstration method through Google Meet on the science learning outcomes of fourth grade students. The type of research is Quantitative Experiment with the True Experimental Design method and the Posttest-Only Control Design research design with a sample of 52 students. Multiple choice test was used as an instrument which was previously tested valid with the Biserial Point Correlation formula and tested for reliability with the KR-20 formula. Data processing through Liliefors normality test and Fisher homogeneity test. The t-test was used to test the hypothesis and the results of tcount $=3.026$ at ttable $=2.0105$, it was concluded that tcount> ttable (3.026>2.0105). Then there is the effect of the demonstration method through Google Meet on the science learning outcomes of fourth grade students at Islamic Elementary School Nurul Hidayah Depok.
\end{abstract}

Keywords: Demonstration method, Google Meet, Science Learning Outcomes.

Copyright (c) 2021 Ibnu Fathoni, Safrul Kodri

$\triangle$ Corresponding author

Email : ibnufathoni99@gmail.com

DOI : https://doi.org/10.31004/edukatif.v3i5.1014

ISSN 2656-8063 (Media Cetak)

ISSN 2656-8071 (Media Online) 
2828 Pengaruh Metode Demonstrasi melalui Google Meet terhadap Hasil Belajar IPA Peserta Didik di Sekolah Dasar-Ibnu Fathoni, Safrul Kodri

DOI : https://doi.org/10.31004/edukatif.v3i5.1014

\section{PENDAHULUAN}

Pembelajaran merupakan proses mengatur kondisi lingkungan disekitar peserta didik agar dapat menarik minat untuk belajar dengan baik (Pane \& Dasopang, 2017). Pelaksanaan pembelajaran di sekolah bertujuan untuk meningkatkan kemampuan pada seseorang terkait aspek pengetahuan, sikap, dan keterampilan maka dari itu setiap proses pembelajaran di kelas dituntut supaya dapat berlangsung secara kondusif dan baik agar tercapainya tujuan pembelajaran secara optimal dengan diterapkannya perangkat pembelajaran yang sesuai dan efektif (Gafur, 2018). Kegiatan pembelajaran yang baik yaitu pembelajaran yang berpusat pada peserta didik sehingga dapat memberikan dampak baik seperti peserta didik lebih aktif dan berpartisipasif di setiap pembelajaran, disiplin dan pandai dalam menginat materi (Arifuddin, 2017).

Salah satu pembelajaran yang dilaksanakan di sekolah yaitu Ilmu Pengetahuan Alam (IPA). Ilmu Pengetahuan Alam atau IPA merupakan salah satu ilmu yang berkaitan tentang bagaimana cara dalam mencari tahu mengenai alam semesta dengan sistematis, oleh karena itu tidak hanya penguasaan pada pengetahuan mengenai fakta, prinsip, atau konsep melainkan juga sebagai bentuk proses penemuan. Hakikat Ilmu Pengetahuan Alam ialah bisa menjadi media bagi peserta didik dalam mempelajari alam sekitar dan dirinya serta dapat dikembangkan secara lanjut agar bisa diterapkan di kehidupan (Saputro, 2018). Lebih lanjut menurut (Samari et al., 2020) pada Sutrisno, dkk (2007:1.19) menjelaskan IPA adalah proses untuk mempelajari alam semesta dengan pengamatan yang sesuai sasaran, menggunakan langkah-langkah yang tepat, dan dapat dipaparkan dengan valid sampai menghasilkan suatu simpulan yang tepat. Dengan tujuan pembelajaran IPA di sekolah yaitu untuk memberikan pemahaman benda-benda alami dan buatan orang serta konsep IPA pada alam sekitar, supaya mempunyai ketrampilan dalam proses atau metode ilmiah yang sederhana dan konkrit pada pelajaran IPA, dapat mengenal dan memecahkan masalah pada alam sekitar melalui sikap ilmiah yang dimiliki, hingga dapat mempunyai konsep dasar yang baiksetelah mempelajari IPA di sekolah dasar (Midianah, 2020).

Sejak wabah covid-19 melanda dunia termasuk Indonesia, hal ini mengakibatkan seluruh aktivitas manusia menjadi terhenti supaya memutus penyebaran virus covid-19 dan mengganggu aspek kehidupan manusia salah satunya yaitu aspek dalam bidang pendidikan. Dari penelitian yang lebih lanjut diketahui bahwa virus covid-19 merupakan suatu virus yang sejenis dengan Severe Acute Respiratory Syndrome (SARS) atau jenis flu pada biasanyadan merupakan virus menular yang dapat menyebabkan penyakit pada sistem pernapasan (Yunitasari \& Hanifah, 2020). Proses pendidikan selama mewabahnya covid-19 di Indonesia dilaksanakan melalui pembelajaran jarak jauh atau daring di rumah, dengan tujuan untuk menghindari dan memutus penyebaran virus covid-19. Pembelajaran beralih secara virtual tanpa ada tatap muka untuk menghentiikan kasus penyebaran covid-19 di Indonesia. Di masa pandemi ini dan proses kegiatan pembelajaran dilaksanakan secara jarak jauh membuat guru untuk menguasai ilmu teknologi dan mengembangkan metode pembelajaran yang inovatif agar pembelajaran berjalan efektif di masa panemi covid-19. Pembelajaran jarak jauh yang dilakukan oleh instansi pendidikan dilakukan menggunakan media aplikasi online atau berbasis internet seperti melalui Whatsaap group, atau aplikasi Google Meet agar dapat memaksimalkan pembelajaran (Andriana et al., 2020). Dilaksanakannyapembelajaran jarak jauh secara online selama pandemi virus covid-19 merupakan suatu penyelesaian masalah pendidikan agar peserta didik dapat mengikuti kegiatan pembelajaran (Ekantini, 2020).

Pembelajaran jarak jauh merupakan jenis salah satu proses belajar mengajar berupa proses sampainya pemahaman materi kepada peserta didik dengan menggunakan internet (Fuadi et al., 2020). Pembelajaran jarak jauh juga dilaksankan melalui media atau perantara berupa jaringan internet dan alat pendukung seperti handphone dan komputer atau laptop (Putria et al., 2020). Dengan diterapkannya pembelajaran jarak jauh, seorang guru diupayakan dapat melakukan suatu inovasi dalam pembelajaran jarak jauh dengan menggunakan metode pembelajaran yang tepat dan sesuai dengan kondisi saat ini dan penggunaan aplikasi berbasis internet 
2829 Pengaruh Metode Demonstrasi melalui Google Meet terhadap Hasil Belajar IPA Peserta Didik di Sekolah Dasar-Ibnu Fathoni, Safrul Kodri

DOI : https://doi.org/10.31004/edukatif.v3i5.1014

untuk menunjang pembelajaran. Metode pembelajaran bisa didefinisikan sebagai bentuk usaha guru dalam mencapai tujuan pembelajaran dengan menyajikan materi kepada peserta didik dengan memperagakan suatu kegiatan (Afif et al., 2019). Salah satu metode pembelajaran yang dapat digunakan adalah metode demonstrasi. Pada metode demonstrasi yang digunakan guru dalam menjelaskan materi dalam pembelajaran dengan memperagakan tahapan atau langkah-langkah kerja secara langsung atau juga bisa menggunakan media yang relevan terkait materi yang disampaikan (Patimapat et al., 2019).

Hasil belajar adalah hasil berupa angka atau nilai yang diterima peserta didik setelah melaksanakan suatu kegiatan pembelajaran pada mata pelajaran tertentu (Kartika, 2021). Sedangkan Hasil belajar IPA berkaitan dengan tujuan pembelajaran IPA yang sudah ditentukan dalam kurikulum tanpa melupakan hakikat pembelajaran IPA. Dan hasil belajar IPA dibedakan berdasarkan hakikat sains yaitu sebagai produk, proses, dan perilaku ilmiah. Jadi dapat dipahami bahwa hasil belajar IPA adalah suatu hasil dari pembelajaran IPA yang meliputi pencapaian IPA sebagai proses, produk, dan perilaku ilmiah (Astari et al., 2018).

Menurut hasil wawancara yang dilakukan peneliti dengan narasumber seorang guru kelas IV di SD Islam Nurul Hidayah yaitu Ibu Eni bahwa pada proses pembelajaran jarak jauh memiliki beberapa kendala seperti adanya kesulitan dalam menentukan metode pembelajaran yang tepat saat pembelajaran jarak jauh dilaksanakan. Sebab pembelajaran tatap muka, guru lebih leluasa berinovasi dalam menerapkan metode pembelajaran. Tetapi mengingat kondisi saat ini yang mewajibkan pembelajaran jarak jauh, maka guru tidak leluasa dalam menerapkan metode dikarenakan kendala lain. Seperti dalam menggunakan aplikasi video conference yang lain seperti Zoom Meeting maka terbatas waktu dan jika disambung pembelajaran lagi dengan masuk menggunakan link, maka terdapat peserta didik yang tidak mengikuti kelas di Zoom Meeting. Kemudian pembelajaran IPA yang biasanya dilakukan dengan melakukan percobaan namun sekarang tidak bisa semenjak pembelajaran jarak juauh dilaksanakan dan ditemukan beberapa kali hasil belajar peserta didik yang tidak maksimal atau banyak yang berada di bawah nilai KKM yaitu 75 .

Menurut permasalahan yang dapat mengganggu hasil belajar peserta didik akibat pembelajaran dilakukan secara jarak jauh, kondisi ini memicu teknologi untuk mengambil peran aktif untuk memfasilitasi proses pembelajaran agar efektif dan efisien yaitu salah satunya Google Meet. Google Meet merupakan sebuah aplikasi dari suatu perangkat komunikasi yang dikenalkan oleh perusahaan Google. Aplikasi Google Meet bisa menjadi wadah untuk mengirim pesan instan, melakukan panggilan video. Google Meet ini diperkenalkan pada tahun 2017 dan pengguna aplikasi ini dapat mengakses secara gratis dan dapat melakukan panggilan video sebanyak 100 pengguna dengan menampilkan hasil video yang berkualitas (Fuadi et al., 2020). Pelaksanaan pembelajaran oleh guru juga dilakukan secara online dengan menggunakan teknologi berbentuk aplikasi berbasis online yang dapat mendukung proses pembelajaran. Teknologi dalam bentuk aplikasi yang digunakan dalam pembelajaran jarak jauh salah satunya adalah Google Meet. Proses pembelajaran daring menggunakan metode demonstrasi melalui Google Meet dilaksanakan selama wabah covid-19 melanda. Google Meet merupakan salah satu layanan dari Google yang dapat menjangkau pembelajaran jarak jauh saat ini, karena melalui Google Meet interaksi dalam pembelajaran terjadi secara interaktif dan menyenangkan dibandingkan dengan layanan lain karena manfaat Google Meet yaitu pengunaannya yang sederhana namun dapat mengakses panggilan video dengan baik (Irmawanty et al., 2020).

Terdapat kelebihan pada penelitian ini yaitu dengan diterapkannya metode demonstrasi melalui Google Meet yang mampu membuat kondisi pembelajaran yang aktif dan efektif dalam menjelaskan materi dan peserta didik dapat melakukan percobaan mengenai materi dengan baik. Sama dengan penelitian yang dilakukan (Juniarti \& Rasna, 2019) bahwa terdapat pengaruh yang baik dalam penggunaan aplikasi Google Meet pada keterampilan menyimak dan berbicara peserta didik pada masa covid-19. Peserta didik menjadi lebih aktif dan merasa seperti melakukan pembelajaran tatap muka saat menggunakan Google Meet dalam pembelajaran, tetapi terdapat kendala seperti koneksi jaringan internet yang kurang stabil dan kapasitas kuota internet yang kurang mencukupi saat menggunakan Google Meet. Dan juga pada penelitian (Gafur, 2018) 
2830 Pengaruh Metode Demonstrasi melalui Google Meet terhadap Hasil Belajar IPA Peserta Didik di Sekolah Dasar-Ibnu Fathoni, Safrul Kodri

DOI : https://doi.org/10.31004/edukatif.v3i5.1014

menyatakan hasil pada penelitian tersebut yaitu terdapat penigkatan hasil belajar pada materi sumber energi dari penerapan metode demonstrasi yang dilakukan peneliti.

Maka pokok pelaksanaan penelitian ini yaitu pada pengaruh metode demonstrasi melalui Google Meet terhadap hasil belajar IPA peserta didik kelas IV. Maka penelitian ini bertujuan untuk membuktikan apakah ada pengaruh metode demonstrasi melalui Google Meet terhadap hasil belajar IPA peserta didik kelas IV di SD Islam Nurul Hidayah Depok. Berhasilnya penelitin ini dapat dilihat melalui data kuantitatif.

\section{METODE PENELITIAN}

Tempat pelaksanan penelitian yaitu di SD Islam Nurul Hidayah Depok dan diteliti pada tahun ajaran 2020/2021 di semester genap. Jenis penelitian yang dilakukan adalah "Kuantitatif Eskperimen" pada metode True Experiment Design dan dengan menggunakan desain penelitian Posttest Only Control Design. Populasi menurut (Siregar, 2018, p. 30) adalah jumlah keseluruhan dari objek pada penelitian yang bisa berupa manusia, hewan, nilai, peristiwa, dan sebagainya yang dapat menjadi sumber data dalam penelitian, sehingga populasi penelitian ini adalah seluruh peserta didik kelas IV yang berjumlah 102 anak. Sampel yaitu sebagian objek yang akan diteliti dari jumlah populasi yang ditentukan (Sumbi \& Rupa, 2021). Penentuan sampel dengan teknik Simple Random Sampling dan didapatkan sampel berjumlah 52 anak yaitu 26 peserta didik pada grup eksperimen dan 26 peserta didik pada grup kontrol.

Pengumpulan data hasil belajar yaitu memanfaatkan instrumen berbentuk soal pilihan ganda. Sebelumnya instrumen berjumlah 40 butir soal akan diuji pada 26 peserta didik kelas IV di kelas yang berbeda agar mendapatkan butir soal yang valid dan reliabel untuk ditetapkan sebagai instrumen penelitian. Uji validitas digunakan untuk menguji setiap nomor soal menggunakan rumus Korelasi Point Biserial dengan kriteria soal yang valid yaitu $r_{\text {hitung }}>r_{\text {tabel }}$. Dengan diperoleh soal yang valid, selanjutnya diuji kembali dengan rumus KR-20 untuk melihat bahwa instrumen tersebut reliabel atau tidak dengan kriteria $r_{\text {hitung }}>r_{\text {tabel }}$.

Data posttest yang telah diperoleh akan diolah dan diuji normalitas dan uji homogenitas serta pengujian hipotesis. Uji normalitas menggunakan rumus Liliefors bertujuan mendapati apakah data berdistribusi normal atau tidak dengan kriteria data berdistribusi normal yaitu jika $L_{0}<L_{\text {tabel }}$. Kemudian uji homogenitas menggunakan rumus Fisher dengan kriteria data homogen yaitu jika $F_{0}<F_{\text {tabel }}$. Terakhir dilakukan pengujian hipotesis memakai rumus uji-t dengan kriteria jika $t_{\text {hitung }}>t_{\text {tabel }}$ yang bermakna tolak $H_{0}$ dan terima $H_{1}$ sehingga kesimpulannya terdapat pengaruh metode demonstrasi melalui Google Meet terhadap hasil belajar IPA peserta didik kelas IV.

\section{HASIL DAN PEMBAHASAN PENELITIAN}

Berikut data hasil perhitungan pada uji normalitas menggunakan rumus Liliefors dan uji homogenitas menggunakan rumus Fisher serta pengujian hipotesis dengan bantuan Microsoft Excel.

Tabel 1. Hasil Perhitungan Uji Normalitas Data Hasil Belajar

\begin{tabular}{|c|c|c|c|c|}
\hline Grup & Lhitung & Ltabel & Kriteria & Keterangan \\
\hline Eksperimen & 0,1026 & 0,1738 & \multirow{2}{*}{ Lo $<$ Ltabe } & \multirow{2}{*}{ Normal } \\
\hline Kontrol & 0,0892 & 0,1738 & & \\
\hline
\end{tabular}

Tabel 1 di atas merupakan hasil perhitungan uji normalitas melalui rumus Liliefors. Hasil perhitungan di atas menunjukkan bahwa uji normalitas pada grup eksperimen dan grup kontrol diperoleh data berdistribusi normal $($ Lo $<$ Ltabel $)$ pada taraf signifikan $\mathrm{a}=5 \%$ atau $0,05, \mathrm{n}$ grup eksperimen $=26$ dan $\mathrm{n}$ grup kontrol $=26$. 
2831 Pengaruh Metode Demonstrasi melalui Google Meet terhadap Hasil Belajar IPA Peserta Didik di Sekolah Dasar-Ibnu Fathoni, Safrul Kodri

DOI : https://doi.org/10.31004/edukatif.v3i5.1014

Maka dapat disimpulkan bahwa data perhitungan uji normalitas hasil belajar penelitian ini yaitu berdistribusi normal.

Tabel 2. Hasil Perhitungan Uji Homogenitas Data Hasil Belajar

\begin{tabular}{|c|c|c|c|c|c|}
\hline Grup & Varians & Fhitung & Ftabel & Kriteria & Keterangan \\
\hline Eksperimen & 70,925 & \multirow{2}{*}{1,663} & \multirow{2}{*}{1,955} & \multirow{2}{*}{ Fo $<$ Ftabel } & \multirow{2}{*}{ Homogen } \\
\hline Kontrol & 117,926 & & & & \\
\hline
\end{tabular}

Tabel 2 di atas merupakan hasil perhitungan uji homogenitas dengan menggunakan rumus Fisher. Hasil perhitungan di atas menunjukkan bahwa uji homogenitas menghasilkan data yang bersifat homogen (Fo < Ftabel) dengan perolehan nilai $F o=1,663$ dan Ftabel $=1,955$ pada taraf signifikansi a $=5 \%$ atau 0,05 dengan df pembilang $=25$ dan df penyebut $=25$. Maka disimpulkan bahwa data perhitungan uji homogenitas data hasil belajar penelitian ini bersifat homogen.

Tabel 2. Hasil Perhitungan Pengujian Hipotesis Data Hasil Belajar

\begin{tabular}{|c|c|c|c|c|c|c|}
\hline Grup & Rerata & Sgab & Dk & thitung & Ttabel & Keterangan \\
\hline Eksperimen & 85,731 & \multirow{2}{*}{9,717} & \multirow{2}{*}{50} & \multirow{2}{*}{3,026} & \multirow{2}{*}{2,0105} & \multirow{2}{*}{ thitung $>$ ttabe } \\
\hline Kontrol & 77,615 & & & & & \\
\hline
\end{tabular}

Setelah melakukan perhitungan dan didapatkan data yang berdistribusi normal dan data yang homogen, maka selanjutnya data diolah pada pengujian hipotesis dengan rumus uji-t hingga diperoleh nilai thitung $=$ 3,026 pada taraf signifikansi $\mathrm{a}=5 \%$ atau 0,05 dan nilai ttabel $=2,0105$ pada derajat kebebasan 50 melalui perhitungan ttabel menggunakan rumus interpolasi. Sehingga hasil pengujian thitung lebih besar dibandingkan ttabel yaitu thitung >ttabel. Maka disimpulkan bahwa tolak $H_{0}$ dan terima $H_{1}$ yang memperlihatkan bahwa hipotesis pada penelitian ini diterima yaitu terdapat pengaruh metode demonstrasi melalui Google Meet terhadap hasil belajar IPA.

Menurut pada hasil di atas dan diketahui bahwa metode demonstrasi melalui Google Meet ini sesuai diterapkan dan dijadikan sebagai penyelesaian masalah pada penelitian ini terhadap rendahnya hasil belajar IPA peserta didik kelas IV akibat pembelajaran jarak jauh yang menyebabkan kurangnya minat dan fokus serta keaktifan peserta didik saat pembelajaran. Adanya pengaruh dikarenakan terdapat perbedaan perlakuan atau treatment saat proses pembelajaran yang berlangsung melalui pembelajaran jarak jauh menggunakan Google Meet. Pada grup eksperimen, peneliti menerapkan metode pembelajaran berupa metode demonstrasi melalui Google Meet terhadap peserta didik yang diteliti, sedangkan pada grup kontrol peserta didik yang diteliti tidak diberi perlakuan atau treatment melainkan dilakukan pembelajaran konvensional berupa ceramah. Kelas IV-B sebagai grup eksperimen memiliki nilai yang lebih tinggi karena metode demonstrasi mempunyai manfaat bagi peserta didik. Metode pembelajaran demonstrasi mampu membuat perhatian dan konsentrasi peserta didik menjadi terpusat dengan penggunaan alat peraga pada metode tersebut, membuat peserta didik cepat memahami materi pembelajaran dan memberi kesan belajar yang bermakna bagi peserta didik, pembelajaran menjadi menarik bagi peserta didik karena peerta didik tidak hanya mendengar penjelasan dari guru melainkan peserta didik dapat melakukan demonstrasi melalui alat peraga yang telah disiapkan sehingga peserta didik tidak cepat bosan dalam pembelajaran melalui Google Meet.

Penelitian ini didukung dan serupa dengan penelitian yang di lakukan oleh (Gafur, 2018) bahwa dengan diterapkannya metode demonstrasi dapat meningkatkan perolehan hasil belajar peserta didik dalam pembelajaran IPA Terpadu dan penelitiannya juga relevan dengan penelitian dari (Aisyah, 2014) yang menyatakan hasil yang diperoleh dalam penelitian yang dilakukan ialah adanya peningkatan yang signifikan pada perolehan hasil belajar peserta didik sebelum dan sesudah melaksanakan pembelajaran IPA dengan penerapan metode demonstrasi. Dan hasil penelitian dari (Juniarti \& Rasna, 2019) yang menyatakan bahwa peserta didik menjadi lebih aktif dan merasa seperti melakukan pembelajaran tatap muka di kelas saat 
2832 Pengaruh Metode Demonstrasi melalui Google Meet terhadap Hasil Belajar IPA Peserta Didik di Sekolah Dasar-Ibnu Fathoni, Safrul Kodri

DOI : https://doi.org/10.31004/edukatif.v3i5.1014

menggunakan Google Meet dalam proses pembelajaran, tetapi terdapat kendala seperti koneksi jaringan internet yang kurang stabil dan kuota internet yang kurang mencukupi saat menggunakan Google Meet. Menurut penjabaran di atas, dapat disimpulkan bahwa sebaiknya guru bisa mengembangkan penguasaan teknologi untuk menunjang pembelajaran jarak jauh dan dibarengi dengan penggunaan metode pembelajaran yang inovatif dan efektif agar kegiatan belajar mengajar menjadi tidak bosan dan bermakna bagi peserta didik hingga merasa senang dan dapat aktif dalam pembelajaran.

Keterbatasan yang dijumpai oleh peneliti pada saat proses penelitian adalah dari segi waktu dan kondisi saat penelitian yang dilakukan secara online tanpa tatap muka dikarenakan wabah covid-19 yang melanda negara diselruh dunia termasuk Indonesia. Karena mewabahnya covid-19 di Indonesia menimbulkan dampak buruk bagi aspek kehidupan manusia terlebih dari aspek pendidikan yang mengharuskan sekolah dilaksanakan secara virtual atau online tanpa tatap muka. Keterbatasan ketersediaan kuota internet masing-masing peserta didik dalam mengakses pembelajaran online. Koneksi jaringan internet yang tidak stabil di masing-masing tempat tinggal peserta didik juga menjadi kendala saat proses pembelajaran. Tidak semua peserta didik dapat hadir dalam aplikasi pembelajaran online. Fokus peserta didik yang tidak bisa berlama-lama dalam pelaksanaan pembelajaran jarak jauh berbasis aplikasi berupa Google Meet. Terkadang proses pembelajaran menjadi tidak kondusif karena dilakukan secara online. Penyelesaian yang dapat dilakukan yaitu sebaiknya guru mempersiapkan dengan baik mengenai pembelajaran jarak jauh yang dilakukan supaya meminimalisir kendala-kendala yang mungkin akan terjadi. Lalu orang tua peserta didik mampu membina dan mengawasi anaknya dalam belajar dan harus membantu mempersiapkan hal-hal yang berkaitan dengan pembelajaran anaknya.

\section{KESIMPULAN}

Menurut penelitian yang sudah dilaksanakan secara online, disimpulkan bahwa perolehan hasil belajar pada grup yang diberi perlakuan metode demonstrasi melalui Google Meet lebih unggul dari perolehan hasil belajar pada grup yang tidak diberi perlakuan metode demonstrasi. Penerapan metode pembelajaran demonstrasi ini mampu memberikan manfaat dan dampak yang baik bagi peserta didik karena suasana pembelajaran menjadi lebih menarik dan tidak membuat bosan sehingga peserta didik ikut aktif pada saat pembelajaran hingga memberi pengalaman belajar yang bermakna dan peserta didik lebih cepat dalam memahami materi.

\section{DAFTARPUSTAKA}

Afif, M., Trisiana, A., \& Handini, O. (2019). Pengaruh Metode Demonstrasi Didukung Video Tematik Integratif P. Jurnal Sinektik Volume 2 Nomor 1, Edisi Juni 2019 Prodi Pgsd Universitas Slamet Riyadi Issn 2620-6560 (Print) Issn 2620-746x (Online), 2(160), 64-76.

Andriana, E., Ramadayanti, S., \& Noviyanti, T. E. (2020). Pembelajaran Ipa Di Sd Pada Masa Covid 19. Prosiding Seminar Nasional Pendidikan Fkip Vol. 3, No.1, 2020, Hal. 409-413, 2017(1), 1-9.

Arifuddin, A. (2017). Pengaruh Metode Demonstrasi Dengan Alat Peraga Jembatan Garis Bilangan Terhadap Hasil Belajar Matematika Materi Bilangan Bulat Ahmad Arifuddin*. Al Ibtida: Jurnal Pendidikan Guru Mi (2017) Vol 4 (2): 165-178, 4, 165-178. Https://Doi.Org/Http://Dx.Doi.Org/ 10.24235/Al.Ibtida.Snj.V4i2.1834

Astari, F. A., Suroso, S., \& Yustinus, Y. (2018). Efektifitas Penggunaan Model Discovery Learning Dan Model Problem Based Learning Terhadap Hasil Belajar Ipa Siswa Kelas 3 Sd. Jurnal Basicedu, 2(1), 110. Https://Doi.Org/10.31004/Basicedu.V2i1.20

Ekantini, A. (2020). Efektivitas Pembelajaran Daring Pada Mata Pelajaran Ipa Di Masa Pandemi Covid-19: 
2833 Pengaruh Metode Demonstrasi melalui Google Meet terhadap Hasil Belajar IPA Peserta Didik di Sekolah Dasar-Ibnu Fathoni, Safrul Kodri

DOI : https://doi.org/10.31004/edukatif.v3i5.1014

Studi Komparasi Pembelajaran Luring Dan Daring Pada Mata Pelajaran Ipa Smp. Jurnal Pendidikan Madrasah, Volume 5, Nomor 2, November 2020, 5(2), 187-194.

Fuadi, T. M., Musriandi, R., \& Suryani, L. (2020). Covid-19 : Penerapan Pembelajaran Daring Di Perguruan Tinggi. Jurnal Dedikasi Pendidikan, 4(2), 193-200.

Gafur, A. (2018). Peningkatan Hasil Belajar Ipa Terpadu Melalui Metode Demonstrasi Pada Siswa Kelas Viii Smp Negeri 2 Sano Nggoang Manggarai Barat Tahun Pelajaran 2017/2018. Jurnal Ilmu Sosial Dan Pendidikan Vol. 2 No. 1 Maret 2018, 2(1), 144-161.

Irmawanty, Sumantri, M. S., \& Japar, M. (2020). Pendampingan Menulis Karya Tulis Ilmiah (Kti) Pada Guru Madrasah Ibtidaiyah Secara Online Dengan Menggunakan Google Meet. Prosiding Seminar Nasional Pascasarjana Universitas Negeri Jakarta, 146-153.

Juniarti, N., \& Rasna, I. (2019). Pemanfaatan Aplikasi Google Meet Dalam Keterampilan Menyimak Dan Berbicara Untuk Pembelajaran Bahasa Pada Masa Pandemi Covid-19. Jurnal Pendidikan Dan Pembelajaran Bahasa Indonesia Vol 9 No 2, Oktober 2020, 8(2), 95-102.

Kartika, W. I. (2021). Pendidikan Hubungan Antara Lingkungan Keluarga Dan Hasil Belajar Ips Siswa Di Sekolah Dasar. Edukatif: Jurnal Ilmu Pendidikan Volume 3 Nomor 4 Tahun 2021 Halm 1318 - 1325 Edukatif: Jurnal Ilmu Pendidikan, 3(4), 1318-1325. Https://Doi.Org/Https://Doi.Org/10.31004/Edukatif.V3i4.555

Midianah. (2020). Pengaruh Metode Demonstrasi Terhadap Peningkatan Hasil Belajar Siswa Kelas Iii Sdn 168 Seluma. Ghaitsa: Islamic Education Journal Vol (1) Issue (1) 2020 Https://Siducat.Org/Index.Php/Ghaitsa, 1, 15-31.

Pane, A., \& Dasopang, M. D. (2017). Belajar Dan Pembelajaran. Fitrah:Jurnal Kajian Ilmu-Ilmu Keislaman, 3(2), 333. Https://Doi.Org/10.24952/Fitrah.V3i2.945

Patimapat, M., Duda, H. J., \& Supiandi, M. I. (2019). Efektivitas Model Pembelajaran Inkuiri Terbimbing Melalui Metode Demonstrasi Terhadap Hasil Belajar Psikomotorik Siswa. 4(2019), 9-20. Https://Doi.Org/10.31932/Jpbio.V4i1.366

Putria, H., Maula, L. H., \& Uswatun, D. A. (2020). Analisis Proses Pembelajaran Dalam Jaringan (Daring) Masa Pandemi Covid-19 Pada Guru Sekolah Dasar. Jurnal Basicedu, 4(4), 861-872. Https://Doi.Org/10.31004/Basicedu.V4i4.460

Samari, S. Y., Sutisnawati, A., \& Amalia, A. R. (2020). Analisis Hasil Belajar Ipa Dalam Pembelajaran Daring Di Sdn Tanjungsari. Jikap Pgsd: Jurnal Ilmiah Ilmu Kependidikan, 4(3), 227. Https://Doi.Org/10.26858/Jkp.V4i3.14753

Saputro, B. C. (2018). Meningkatkan Hasil Belajar Sifat-Sifat Cahaya Dengan Metode Inkuiri Pada Kelas V Semester Ii Sd Negeri Sumogawe 04. Jurnal Mitra Pendidikan, 1(9), 11-22.

Siregar, S. (2018). Metode Penelitian Kuantitatif (2018th Ed.). Kencana Prenada Media Group.

Sumbi, A. K., \& Rupa, J. N. (2021). Kemampuan Menentukan Kalimat Persuasif Dalam Teks Negosiasi Siswa Sma. Edukatif: Jurnal Ilmu Pendidikan Volume 3 Nomor 4 Tahun 2021 Halm 1798 - 1807 Edukatif: Jurnal Ilmu Pendidikan Research \& Learning In Education Https: // Edukatif.Org/Index.Php/ Edukatif/Index, 3(4), 1798-1807. Https://Doi.Org/Https://Doi.Org/10.31004/Edukatif.V3i4.689

Yunitasari, R., \& Hanifah, U. (2020). Pengaruh Pembelajaran Daring Terhadap Minat Belajar Siswa Pada Masa Covid-19. Edukatif: Jurnal Ilmu Pendidikan Research \& Learning In Education, 2(3), 232-243. Https://Doi.Org/Https://Doi.Org/10.31004/Edukatif.V2i3.142 Copyright 